\title{
LARO (Learners Active Response to Operant) lessons in improving the basic science process skills of elementary pupils
}

\author{
Aureen Kate A. Barantes a,1, Joseline R. Tamoria a,2,* \\ a College of Teacher Education, President Ramon Magsaysay State University, Zambales 2207, Philippines \\ ${ }^{1}$ akalba2408@gmail.com; ${ }^{2}$ ceas_sm@prmsu.edu.ph ${ }^{*}$ \\ ${ }^{*}$ Corresponding author
}

\begin{tabular}{|c|c|}
\hline ARTICLE INFO & ABSTRACT \\
\hline $\begin{array}{l}\text { Article history } \\
\text { Received: } 7 \text { February } 2021 \\
\text { Revised: } 11 \text { March } 2021 \\
\text { Accepted: } 17 \text { March } 2021 \\
\text { Published: } 31 \text { March } 2021 \\
\text { Keywords } \\
\text { Action research } \\
\text { Basic science process skills } \\
\text { Elementary teaching } \\
\text { LARO lessons } \\
\text { Science education }\end{array}$ & $\begin{array}{l}\text { Science is regularly taught in ways that make the data unessential, theoretical, } \\
\text { and disengaged from students' experiences. Although most students do anticipate to } \\
\text { learn science, they regularly see it as being presented in uninteresting ways. This study } \\
\text { aimed to determine the effectiveness of using LARO (Learners Active Response to } \\
\text { Operant) lessons in teaching biology and their roles in promoting students' basic } \\
\text { science process skills (BSPS). This action research employed a descriptive research } \\
\text { design. Thirty Grade IV pupils in a special education-gifted talented (SPED-GT) } \\
\text { elementary school in Zambales, Philippines, were selected using convenience } \\
\text { sampling. A parallel test was used to determine the level of BSPS before and after the } \\
\text { application of LARO lessons. Results revealed that before the utilization of LARO } \\
\text { lessons, it was found out that some of the pupils had advance knowledge and they were } \\
\text { under the average level of basic science process skills. Throughout the use of } \\
\text { educational games, there is an improvement in pupils' performance on their oral } \\
\text { participation as recorded in their daily recitation logs. It only shows that the pupils are } \\
\text { eagerly motivated. After the use of LARO, pupils improved from average to outstanding } \\
\text { level of performance of their BSPS in the post-test. It was revealed by the result of the t- } \\
\text { test that LARO lessons were effective in enhancing the basic science process skills of } \\
\text { pupils. The researchers recommend the use of LARO lessons as a technique to } \\
\text { improve the pupil's BSPS. }\end{array}$ \\
\hline
\end{tabular}

Copyright (c) 2021, Barantes \& Tamoria This is an open access article under the CC-BY-SA license

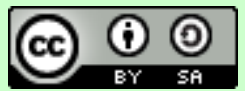

How to cite: Barantes, A.K.A., \& Tamoria, J.R. (2021). LARO (Learners Active Response to Operant) lessons in improving the basic science process skills of elementary pupils. JPBI (Jurnal Pendidikan Biologi Indonesia), 7(1), 11-24. doi: https:// doi.org/10.22219/jpbi.v7i1.15510

\section{INTRODUCTION}

Education and fun can go hand in hand and can be seen in educational games. Games are synonymous with play, and play is our brain's favorite way of learning. Regardless of age, gender, nor interests, it is a known fact that pupils learn best through play.

Al-Tarawneh (2016) cited that science teachers, and researchers believed that all students could be proficient in learning science, specifically biology, in a more learner-centered curriculum than teachercentered or using the traditional teaching method. Science curriculum revolves around scientific concepts that 
are considered as the foundation of scientific knowledge. Those concepts permit us to draw suitable conclusions about the individuals that we encounter in our everyday lives. Despite the importance of scientific concepts, students confront challenges in obtaining these concepts, specifically in elementary years. Students lack scientific background that leads them to confusion between scientific terms and their meaning. These complications are characterized by implementing traditional science learning. Traditional science learning has been assessed for not capturing learner's interests and cultivating a more profound understanding. This is supported by several studies (Bajak, 2014; Yen et al., 2013).

Meanwhile, educators believe the difficulties stated can be tamed by utilizing eagerness and fun-based teaching and learning strategies. The learner gains real-life experience from his/ her active participation in the learning process, and motivational games are considered one method to attain fun-based teaching. Psychologists have long recognized the significance of play in cognitive development and learning. For instance, Piaget considered play as being "integral to, and evolving with, children's stages of cognitive development" (Plass et al. 2015).

The usefulness of science links to technology and industry. This has a big help in the national perspective which are a high priority for development. Science improves students' scientific inquiry skills, critical thinking, values, and attitudes, such as objectivity, curiosity, and honesty. These skills are beneficial to every individual, especially students, for his improvement, future career, and life, in general. These are useful to the community where an individual belongs and are further useful to the nation that he lives (SEI-DOST \& UP NISMED, 2011). Through the advent of technology, Science has become a potent tool in analyzing, exploring, and discovering new concepts and ideas relevant in today's generation (Macanas \& Rogayan, 2020).

Science is commonly taught in ways that make the data unessential, theoretical, and disengaged from learners' experiences. Even though most students expect to learn science, they commonly see it being presented in an uninteresting and monotonous way. This frequently leads to students not appreciating and valuing science activities, seeing Science as not personally necessary to their lives (National Research Council, 1997).

Science subject is one of the shortcomings of the Flipino students. Many educators nationwide had to adapt to the changes brought by the new curriculum in the hope of producing holistically-developed and globally competitive learners, especially in Science (Tolentino et al., 2018). The most common causes gathered are a negative attitude towards the subject, poor study habits, dislike towards the teacher, teaching strategy, and lack of drive-in learning science.

The study of SEI-DOST and UP NISMED (2011) revealed that Filipino students have low retention of concepts, limited reasoning and logical skills, and poor communication skills as they cannot express ideas or explanations in their own words. From Philippine Daily Inquirer (2017) in the Trends in International Mathematics and Science Study (TIMMS), the year 1999 and 2003 was the last time the Philippines participated in this assessment, with the following scores 378 and ranked 34th of 38 countries in Math and $43 r d$ of 46 th in science. The country stopped participating in the survey in 2008 , perhaps after getting such low scores.

Learning how to think critically is one essential skill teachers want the learners to manifest. The six basic science process skills (BSPS) are essential for the foundation of critical thinking. Primary grades can acquire and exercise the most basic skills, namely: observing, classifying, inferring, measuring, predicting, and communicating - using various fun and engaging activities. Teachers must continue to innovate strategies and approaches to make science teaching more engaging, fun, and collaborative (Rogayan \& Macanas, 2020).

For the teaching and learning process to be effective, it is better to create a conducive atmosphere and involve students actively in learning. LARO (Learners Active Response to Operant) Lessons are used to different classroom activities in science. LARO includes games and exciting activities in Science lessons to sustain pupils' interest from the beginning until the end of the lesson. These are not only motivational games but also games in the lesson. Games and other forms of play make every student excited and active participant in the class. For every activity introduced, it always followed by varied activities to increase class participation. The games used in this study are described in the paper and are utilized to increase students' BSPS. Therefore, teachers must be a collaborator, a guide that will organize the educational process and an educator who will teach innovatively and help the learners effectively develop the necessary skills (Fiksl et al., 2017). 
Sustaining young learners' interest is challenging because they have less attention span at an early age. In recent years, numerous researchers have conveyed the positive influence of motivational games on developing students' learning. Al-Tarawneh (2016) quoted games have great potential in nurturing children's ability to interact and converse with others through gameplay. As cited in Al-Mutawah and Fateel (2018), Gardner verified that the primary and crucial purpose of science learning is to stir every child's sense of enjoyment, interest, and intellectual power in science. Therefore, students are academically motivated to maintain a high ability and competence in their work by playing games. The games used in the study are games which address different styles of learners such as visual, auditory, kinesthetic and linguistic learners. The games were designed to suit the grade level of the learners.

According to Graafland et al (2012), there are few researches about educational games' effectiveness in different subject matters like history, sociology, anthropology and literature, and more. However, educational games are more prevalent in the science subject because it represents the ideal playground to engage students in complex virtual decision-making processes.

The Filipino researchers, Libradilla et al (2015) stressed that students need motivation that energizes, directs, and sustains positive behavior. It gets them moving, helps achieve a particular direction, keeps them going because a motivated learner performs well. The games were modified and contextualized from the existing games recommended by the education department and games that pupils encounter online.

This study aimed to determine the effectiveness of using LARO lessons in teaching science and their role in promoting students' level of science process skills.

\section{METHOD}

The study used an action research design. The study used the pre-test and post-test to obtain data and information needed to determine the effects of LARO lessons. This study focused on how pupils' basic science process skills were improved using LARO lessons in teaching science. The data were collected and analyzed quantitatively.

The thirty Grade-IV pupils in a special education-gifted talented (SPED-GT) elementary school in Zambales, Philippines, were the participants of this research. The Grade-IV class was composed of sixteen (16) male and fourteen (14) female pupils. The subjects' ages ranged from 10-11 years old. A convenient sampling technique was used in selecting the participants. The subjects were selected because they were the assigned class in Practice Teaching. The researchers used convenience sampling not just because it is easy to use but because it also has another research advantage. In pilot studies, convenience sampling is usually used because it allows the researcher to obtain necessary data and trends regarding the research without the complications of using that particular quality of a substance or phenomenon that occurs within a given sample. Such studies are also beneficial for detecting relationships among different phenomena (Explorable, 2017).

The researchers used the teaching plan, and pre-test and post-test as instruments of the study. The teaching plan was composed of the teaching units and objectives which were acquired from the lessons prescribed by the Department of Education (DepEd) under the K-12 Enhanced Basic Education Curriculum Guide in Science Grade IV. This study's teaching unit was focused on plants and animals that all fall under the second quarter.

A 30-item parallel test or equivalent test aligned to the Second Quarter period has been made to determine the level of BSPS among Grade IV pupils. The BSPS in the test were measured using the six skills, namely; observing ( 8 items), measuring ( 4 items), inferring ( 7 items), communicating ( 3 items), classifying ( 5 items) and predicting (3 items), carefully planned using Table of Specification (TOS). The test underwent pilot testing and item analysis to test the vocabulary load and clarity of expressions. Sixteen (16) or $53.33 \%$ items were retained, twelve (12) or $40 \%$ were revised and two (2) or $6.67 \%$ were rejected. The retained items were modified while the rejected items were changed. Item analysis is a process which examines learner responses to individual test items or questions to evaluate the quality of these items and of the test as a whole (University of Washington, n.d.).

For data gathering, the researchers requested approval from the Principal for the conduct of the study. A diagnostic test (Pre-test) and summative test- parallel test were made to measure the students' level of Basic Science Process before applying LARO lessons. The test was validated by a college instructor and an elementary school teacher. It is composed of thirty (30) multiple-choice items exemplifying the Science Skills and has been tried out to 30 pupils of the other Grade IV section. Administration of pilot testing and item analysis was made. The test was piloted to Grade IV Pupils under the regular curriculum of a public 
elementary school. The pre-test was then administered to the students. LARO lessons were applied to the lessons for the whole duration of the $2^{\text {nd }}$ grading period. The games used and its descriptions are discussed in the results. The researchers also used recitation logs, group performance logs, laboratory experiments, and reflective journals to record the improvements of the students' performances. After six weeks of teaching, a parallel test (Post-test) has been administered.

The data gathered were analyzed and interpreted using different statistical tools. The item analysis was used to determine the vocabulary clarity of expression, and examine the students' response per item after the pilot testing. The frequency and percent distribution were used to present data in a tabular format which contains the frequency of students grouped according to level of academic performance. The mean was used to determine the level of the Grade IV pupils during pre-test and post-test. The score interpretation is as follows: 25-30 (outstanding), 19-24 (above average), 13-18 (average), 7-12 (below average), and 1-6 poor). The total items of the test are 30 . The mean percent score indicates the ratio between the number of correctly answered items and the total number of test questions or the percentage of correctly answered items in a test. Standard deviation was used to determine the spread of scores which clusters towards the mean. It is to measure how the class is distributed. The dependent t-test was used in determining if there is a significant difference between the pre-test and post-test.

\section{RESULTS AND DISCUSSION}

Earlier before the intervention, class observations took place. Grade IV pupils' BSPS were not noticeable during recitations, group performances, discussions, and activities as analyzed. It was witnessed that the teaching strategies and methods were typical, predictable, and traditionally done. By that, it was found out that pupils were hesitant in giving comments and reactions, where they have difficulty trying to find particular ways to solve problems and lack of opportunity to observe, handle and explore things.

Science is taught by doing and helping in the mastery of the different Science Process Skills. A pre-test was administered to identify the pupils' strengths and weaknesses on the topics of Science IV. The pre-test is composed of thirty (30) items that were carefully planned in consultation with the cooperating teacher guided by DepEd learning competencies to assess pupils' BSPS in Science.

Table 1 shows the level of Science Process Skills of Grade IV Pupils in the pre-test. Out of the thirty (30) students, five (5) pupils or $16.67 \%$ got a score under outstanding, while one (1) got a score below average. The mean of the scores 16.06, described an average level of performance. The standard deviation of 3.54 shows that the class is homogeneous. During the administration of the test, the pupils seemed to be relaxed and focused on answering. Since the Grade IV Pupils are categorized as SPED-GT, it was expected that some of them had an advanced knowledge described as an average performance about the topics in the exam.

Table 1. Frequency and percent distribution of the respondents' score in the pre-test

\begin{tabular}{cccc}
\hline Class interval & Frequency & Percentage $(\%)$ & Descriptive rating \\
\hline $25-30$ & 5 & 16.67 & Outstanding \\
$19-24$ & 17 & 56.67 & Above Average \\
$13-18$ & 7 & 23.33 & Average \\
$7-12$ & 1 & 3.33 & Below Average \\
Total & 30 & 100.0 & \\
\hline \multicolumn{4}{c}{} \\
\hline
\end{tabular}

Students have pre-existing knowledge of the lessons; this may influence how they deal, analyze, and organize the information. Assessment of prior knowledge and skill brings about a range of potential responses and uniformity of results (Acero, 2015).

In the pre-test, a frequency and percent of correct answers were attained to define their achievement in every learning competency in the science curriculum. There were eight learning competencies considered in the pre-test. Table 2 indicates the number of pupils who got the items correctly. It was evident that in items number $16-19$ got the highest percent of $82.22 \%$ associated with the competency "Identify the specialized structures of terrestrial and aquatic plants." The questions included on those items were all about plants' structures that protect them from their prey. It was assessed to fall under Observing and Inferring Skills.

The $\mathrm{K}$ to 12 Science curriculum provides learners a collection of competencies crucial in a knowledgebased society. Organizing the curriculum around situations and problems that challenge and arouse students' curiosity motivates them to learn and appreciate Science as relevant and useful (Department of 
Education, 2012). Competencies are combined attitudes, skills and knowledge, students have to develop and apply for successful learning. These will further help students discover and construct knowledge, strategized thinking and find out better solutions. Students use and develop competencies when encountering unexperienced and challenging circumstances by learning the subject contents and experiences (Alberta Education, 2012).

Table 2. Frequency of correct answers per learning competency in the pre-test

\begin{tabular}{|c|c|c|c|}
\hline Learning competency & Item No. & $\begin{array}{l}\text { Mean frequency of } \\
\text { correct answers }\end{array}$ & Percentage (\%) \\
\hline $\begin{array}{l}\text { 1. Infer that body structures help animal adapt and survive } \\
\text { in their particular habitat. ( } 4 \text { items) }\end{array}$ & $1-4$ & 24.75 & 83.00 \\
\hline $\begin{array}{l}\text { 2. Compare body movements of animals in their habitat. (4 } \\
\text { items) }\end{array}$ & $5-8$ & 20.25 & 68.00 \\
\hline $\begin{array}{l}\text { 3. Make a survey of animals found in the community and } \\
\text { their specific habitat. ( } 4 \text { items) }\end{array}$ & $9-12$ & 21.50 & 72.00 \\
\hline $\begin{array}{l}\text { 4. Choose which animals to raise in a particular habitat. ( } 3 \\
\text { items) }\end{array}$ & $13-15$ & 21.25 & 72.00 \\
\hline $\begin{array}{l}\text { 5. Identify the specialized structures of terrestrial and } \\
\text { aquatic plants. }\end{array}$ & $16-19$ & 24.67 & 82.22 \\
\hline $\begin{array}{l}\text { 6. Investigate the specialized structures of plants given } \\
\text { varying environmental conditions: light, water, temperature } \\
\text { and soil type. }\end{array}$ & $20-23$ & 24.00 & 80.00 \\
\hline $\begin{array}{l}\text { 7. Survey plants found in the community and their specific } \\
\text { habitats. }\end{array}$ & $24-26$ & 16.25 & 72.00 \\
\hline 8. Choose which plants to grow in a particular habitat. & $27-30$ & 18.00 & 60.00 \\
\hline
\end{tabular}

It revealed that the respondents had advanced knowledge on the questions number 16-19 because it was an observation question based on their environment. The result is supported by SEAMEO INNOTECH (2016) to enhance creativity and use the environment as a topic. Exposing pupils to the environment increase their awareness of what is happening around them. The social aspect includes learning environment which seems to affirm the consistency of relationship between learning environment and students' cognitive as well as effective outcomes (Ashby et al., 2011).

The overall result was quite good. Poorly, the lowest percent of items that students' answered was itemnumber 27-30. As observed, the competency was relatively easy to attain, but on the other way, the students reacted upon the new questions which they found difficult to answer because some terms aren't yet introduced to them. Examples of these terms include names of plants like daisy, bangar, sampaguita and bougainvillea, and talahib. Tizon (2009) states that sometimes, unfamiliar to a specific word or language can badly limit communication. Second language learners sometimes have an insufficient vocabulary that will lead to poor comprehension. The questions on the items were categorized under classifying and inferring skills.

The activities presented in the study is anchored in the Principle of Sequence states that successful instructions depend on the practical ordering of a series of learning tasks (Acero, 2015). After the pre-test, the teacher-implementer was challenged to teach Science in a more collaborative manner and came into thinking to use educational games to uphold the pupils' level of BSPS. Since games are one major collaborative activity, it became a part of every 50-minute lessons in the Science subject.

Under the theory of practice, also known as Piaget's theory of Constructivism, people learn by doing, we gain and learn meanings based upon our experiences and everyday exploration of things. Therefore, actively engaging and exposing learners in experience-based learning is critical to the construction of new meaning. Zulueta (2007) strongly emphasized that the more senses are actively used in the learning process, the better could be the contribution to learning. Some students are indeed enthusiastic about learning, need-or expect-their instructors to inspire, challenge, and stimulate them. LARO lessons are one possible thing that may fit those described explanations.

Games make pupils awake, actively participate and accept that it is a factor to sustain interest in any task. Sustaining interest in the subject is a challenging task, but once games are introduced, pupils enjoy and learning is positive. The most essential benefit of games is to "engage players in effortless learning by creating the right level of engagement, just between boredom and frustration" (Plass et al., 2015). 
Table 3 shows the motivational games and its description used in focused topics in Science for Grade IV under the $2^{\text {nd }}$ grading period. The games have catchy engaging titles used to latch pupils' attention and curiosity. These games are considered as an excellent instructional aid for learning Science. To make the class active and enthusiastic, Kamra (2010) emphasized that games are an efficient way to teach English. Every teacher wants the best learning outcome that is meaningful and permanent.

Table 3. LARO for basic science process skills and their descriptions

\begin{tabular}{|c|c|c|c|}
\hline Topic & $\begin{array}{l}\text { Motivational } \\
\text { games }\end{array}$ & Description & Target BSPS \\
\hline $\begin{array}{l}\text { 1.1 Body Parts } \\
\text { of Animals that } \\
\text { Live in Water } \\
\text { and in Land }\end{array}$ & $\begin{array}{l}\text { "4 pics } 1 \\
\text { Word" } \\
\text { "Act, Like and } \\
\text { Tell" }\end{array}$ & $\begin{array}{l}\text {-They will guess four photographs that have something in common } \\
\text { using the blank spaces below it, indicating how many letters are in } \\
\text { the answer. } \\
\text {-Played by partners. Given } 5 \text { animals, one member will act the given } \\
\text { animal's traits and behaviour, and the other pupil will tell what it is. }\end{array}$ & $\begin{array}{l}\text { Observing, Classifying } \\
\text { Measuring, } \\
\text { Inferring, } \\
\text { Predicting } \\
\text { Communicating }\end{array}$ \\
\hline $\begin{array}{l}\text { 1.2 Body Parts } \\
\text { of Animals for } \\
\text { Food Getting/ } \\
\text { Eating }\end{array}$ & "Pictoword" & $\begin{array}{l}\text { Creating and combining words based on the picture. For example, } \\
\text { picture of SAND and WITCH, combined to solve for SANDWICH. }\end{array}$ & $\begin{array}{l}\text { Observing, Classifying } \\
\text { Measuring, } \\
\text { Predicting } \\
\text { Communicating }\end{array}$ \\
\hline $\begin{array}{l}\text { 1.3 Body Parts } \\
\text { of Animals for } \\
\text { Protection }\end{array}$ & $\begin{array}{l}\text { "You are What } \\
\text { You Eat" }\end{array}$ & $\begin{array}{l}\text { Hide pictures or toy animal creatures inside the room. The creature } \\
\text { or those animals will be the prey or the animals have eaten, and the } \\
\text { pupils will be the seeker of an animal who eats other animals. The } \\
\text { fastest pupil who will find the creature will be the winner. }\end{array}$ & $\begin{array}{l}\text { Observing, Classifying } \\
\text { Measuring, } \\
\text { and Communicating }\end{array}$ \\
\hline $\begin{array}{l}\text { 1.4Animal } \\
\text { Movements in } \\
\text { Particular } \\
\text { Habitat }\end{array}$ & "Mimic Match" & $\begin{array}{l}\text { The students will crawl around mimicking the sounds of the animal } \\
\text { they drew from a bowl of names. They are not allowed to talk but can } \\
\text { make animal sounds as they try to find the other animals just like } \\
\text { them and determine which habitat that particular animal lives. }\end{array}$ & $\begin{array}{l}\text { Observing, Classifying } \\
\text { Inferring, } \\
\text { and Communicating }\end{array}$ \\
\hline $\begin{array}{l}\text { 1.5Animals } \\
\text { Found in the } \\
\text { Community }\end{array}$ & $\begin{array}{l}\text { "Meet Me } \\
\text { Through My } \\
\text { Sound" }\end{array}$ & $\begin{array}{l}\text { Blindfold each member in a group and play an animal sound for them } \\
\text { to guess. The group who got the most correct answers wins. }\end{array}$ & $\begin{array}{l}\text { Observing, Classifying } \\
\text { and Communicating }\end{array}$ \\
\hline $\begin{array}{l}\text { 1.6 Life Cycle } \\
\text { of Selected } \\
\text { Animals; } \\
\text { Complete and } \\
\text { Incomplete } \\
\text { Metamorphosis }\end{array}$ & $\begin{array}{l}\text { "Puzzle } \\
\text { Geeks" }\end{array}$ & $\begin{array}{l}\text { Let them solve the wooden puzzle and explain their observations } \\
\text { about the puzzle using Venn diagram. }\end{array}$ & $\begin{array}{l}\text { Classifying } \\
\text { Measuring, } \\
\text { Inferring, } \\
\text { Predicting and } \\
\text { Communicating }\end{array}$ \\
\hline $\begin{array}{l}1.7 \text { Life Cycle } \\
\text { of Egg Laying } \\
\text { Animals }\end{array}$ & $\begin{array}{l}\text { "Body } \\
\text { Twisters" }\end{array}$ & $\begin{array}{l}\text { Each group has to think of an animal that lays eggs and have to use } \\
\text { their bodies to spell the letters for the other groups to guess. }\end{array}$ & $\begin{array}{l}\text { Classifying } \\
\text { Measuring, } \\
\text { Inferring, } \\
\text { and Communicating }\end{array}$ \\
\hline $\begin{array}{l}\text { 1.8 Plants that } \\
\text { Live on Land } \\
\text { and Water }\end{array}$ & $\begin{array}{l}\text { "Write If You } \\
\text { Can" }\end{array}$ & $\begin{array}{l}\text { Write as many as plants found in their community. Eliminate or mark } \\
x \text { all plants in common with the other groups. No common plant wins } \\
\text { a point. }\end{array}$ & $\begin{array}{l}\text { Observing, Classifying } \\
\text { Measuring, } \\
\text { Inferring, } \\
\text { and Communicating }\end{array}$ \\
\hline $\begin{array}{l}1.9 \\
\text { Specialized } \\
\text { Structures of } \\
\text { Terrestrial and } \\
\text { Aquatic Plants }\end{array}$ & "Pin Wheel" & $\begin{array}{l}\text { Divide the class into } 5 \text { groups. The leader will roll the wheel. } \\
\text { Whatever category they are, they will think of the things related to } \\
\text { that category/topic. The group who has given the most related } \\
\text { answers win. }\end{array}$ & $\begin{array}{l}\text { Observing, Classifying } \\
\text { Measuring, } \\
\text { Inferring, } \\
\text { Predicting } \\
\text { Communicating }\end{array}$ \\
\hline $\begin{array}{l}\text { 1.10 Choosing } \\
\text { Plants Grow in } \\
\text { Particular } \\
\text { Habitat }\end{array}$ & $\begin{array}{l}\text { "Show me } \\
\text { your } \\
\text { Entrepreneuria } \\
\text { I Skills" }\end{array}$ & $\begin{array}{l}\text { Given the following products, identify where it came from. } \\
\text { 1. pickle } \\
\text { 2. kalamay } \\
\text { 3. peanut butter; } 4 \text {. buko pie } \\
\text { 5. garlic chips; } 6 \text {. Nata de coco } \\
\text { 7. dried mango } \quad \text { 8. ketchup }\end{array}$ & $\begin{array}{l}\text { Observing, Classifying } \\
\text { and } \\
\text { Inferring, }\end{array}$ \\
\hline $\begin{array}{l}1.11 \text { Seed and } \\
\text { its Parts }\end{array}$ & $\begin{array}{l}\text { "Let's be } \\
\text { detectives!" }\end{array}$ & $\begin{array}{l}\text { Two apparently equal pictures given to a student and the counter- } \\
\text { picture to his/her partner. Make the students sit far from his/her } \\
\text { partner in order to describe the picture without looking at the counter } \\
\text { picture. The game's point is to detect the differences without using } \\
\text { body language or looking at the partner's counter-picture. }\end{array}$ & $\begin{array}{l}\text { Observing, Classifying } \\
\text { Measuring, } \\
\text { Inferring, } \\
\text { Predicting } \\
\text { Communicating }\end{array}$ \\
\hline $\begin{array}{l}1.12 \\
\text { Germination } \\
\text { and Growth }\end{array}$ & "Graph Me" & $\begin{array}{l}\text { Use a human bar graph to compare the heights of different groups of } \\
\text { plants. }\end{array}$ & $\begin{array}{l}\text { Observing, } \\
\text { Measuring, } \\
\text { Inferring, } \\
\text { Predicting } \\
\text { Communicating }\end{array}$ \\
\hline
\end{tabular}

Legend: (BSPS) Basic Science Process Skills 
Singh and Padilla (2009) cited that recitation is done when pupils freely talk about matters that interest them, their thinking based on many skills, insights and experiences. Recitation log is a motivational technique encouraging every student to participate actively in the discussion.

Oral questioning was used to evaluate learning during instruction to confirm that students have attained that particular lesson's objectives. As the student recites and performs the tasks in the class, a point is credited to them and recorded in an index card by their seatmate. This is part of the post-game activity.

Table 4 shows the increasing number of questions in the class with relevance to the Science Process Skills. There is increasing progress from August $(47.13 \%)$ to October $(67.88 \%)$ in Grade IV pupils' performance based on their recitations. It only shows that the pupils are motivated to participate in the class discussion actively. The positive response of the students in the questions-built self-confidence and showed excitement in the class.

Table 4. Means of recitation logs of the grade IV pupils

\begin{tabular}{llll}
\hline Month & No. of questions asked & Mean & Percentage (\%) \\
\hline August & 15 & 7.07 & 47.13 \\
September & 20 & 12.33 & 61.65 \\
October & 25 & 16.97 & 67.88 \\
\hline
\end{tabular}

The results conform to Jones et al (2010) as they stated that students participate actively during recitation as they accomplished the games presented. Also, if mistakes were caught, students will clarify their thoughts to the class. With the increasing mean number above, it is evident that the intervention helped the students forget the pressure towards the lesson, boosts their moods and increased their overall motivation. Visual and verbal learners benefitted from this part of the recitation the most. Martinson and Chu (2009) also support this result as games are an effective tool for learning because they offer students a hypothetical environment that they can explore without the risk of failure.

Group activities make students work together to encourage collaborative learning and less threatening (Corpuz \& Salandanan, 2015). Being a part of a group increases self-confidence, sense of responsibility and feeling of belongingness. Group Performance log is a motivational technique promoting collaboration and cooperation in group activities and also encourage individual accountability. Every group activity, the students were given a designated role in a group. There were six group roles: Recorder who acts as a secretary of the group, Reporter who presents the group's ideas to the rest of the class: Encourager who inspires the group members to continue to think through their approaches and ideas, Time Keeper who monitors the time and planning; and Helper who acts as a material manager who picks up, distributes, collects, turns in the materials of his group. Those roles were assigned by the group Leaders who manage the group and ensure that they will stay on tasks. As the students perform the tasks, their group leaders' roles were recorded at the back of their notebooks by their group leaders. Assigning group roles motivates involvement, interdependence, and a fair division of labor. All group members should feel a sense of personal responsibility for their teammates' success and realize that their individual success depends on the group's success.

It was implemented that each of the members will participate and contribute voluntarily depending on their abilities. All the group works or activities were collaboratively planned using motivational games. The work is distributed among the pupils to experience all the group roles in every group works. It emphasizes that learning is effective because of a clear sense that group work serves the stated learning goals, disciplinary thinking goals and peer evaluation of the BSPS being acquired. The activities presented are supported by Acero's (2015) principle of socialization. He stated that learning offers socio-cultural phenomena, a social process that surrounds the way of thinking, interacting and problem-solving. Constructivist theorists believed that social interaction is critical to learning. Viray (2016) stated that games are good for promoting worthy learning because it encourages cooperation among players or learners and thus provides a peer-to-peer teaching situation and development of learning groups. Singh and Padilla (2009) believed that children must learn how to follow a leader, to be a good committee member in every group task.

Science experiments promote discovery and learning. Many researchers revealed positive effects of hands-on experiments in the learners' progress because it is a continuously modified by experiences and it processes concepts derived. Studies have shown that students are very much curious in learning science. With this method curiosity among students will increase as they develop their interest in learning Science 
(Andersen \& Vandehey, 2011; Kolb, 1984; NARST, 2015). Also, they should practice exercises to avoid monotony. This would enable skills development acquisition, so students would be happy and show progress. Table 5 shows the set of experiments performed by the Grade IV pupils aligned to the BSPS. There were six (6) experiments that correspond to six (6) BSPS done during LARO lessons intervention. Each experiment used the rubric consisting of twenty (20) points.

Table 5. Laboratory experiments performed and mean scores by the grade IV pupils

\begin{tabular}{|c|c|c|c|c|}
\hline Topics & Activities & Effects of the activities & Mean score & Target BSPS \\
\hline $\begin{array}{l}\text { Introducing Plants } \\
\text { and Animals }\end{array}$ & $\begin{array}{l}\text { Taking pictures of } \\
\text { plants and animals. }\end{array}$ & $\begin{array}{l}\text { Continue taking pictures } \\
\text { in their own home } \\
\text { gardens and neighbor's } \\
\text { farm animals. }\end{array}$ & 15.8 & $\begin{array}{l}\text { Observing, Classifying, } \\
\text { Measuring, } \\
\text { Inferring, } \\
\text { Predicting } \\
\text { Communicating }\end{array}$ \\
\hline Animals & $\begin{array}{l}\text { Listing and classifying } \\
\text { of domestic animals }\end{array}$ & $\begin{array}{l}\text { Explore the internet on } \\
\text { unfamiliar animals. }\end{array}$ & 17.2 & $\begin{array}{l}\text { Observing } \\
\text { Classifying, } \\
\text { Communicating }\end{array}$ \\
\hline $\begin{array}{l}\text { Animal Body Parts } \\
\text { and Behavior }\end{array}$ & $\begin{array}{l}\text { Describing the behavior } \\
\text { on how they used the } \\
\text { body parts }\end{array}$ & $\begin{array}{l}\text { Download pictures or } \\
\text { videos of animals. }\end{array}$ & 16.5 & $\begin{array}{l}\text { Observing, Classifying, } \\
\text { Inferring, } \\
\text { Predicting Communicating }\end{array}$ \\
\hline Seeds Viability & $\begin{array}{l}\text { Germinating seeds } \\
\text { through wrapping in a } \\
\text { wet tissue paper }\end{array}$ & $\begin{array}{l}\text { Submerged the seeds in } \\
\text { water and sow monggo } \\
\text { seeds on the soil. }\end{array}$ & 14.2 & $\begin{array}{l}\text { Observing, Measuring } \\
\text { Inferring, } \\
\text { Predicting Communicating }\end{array}$ \\
\hline Seed Germination & $\begin{array}{l}\text { Measuring the plant } \\
\text { from seed to baby plant }\end{array}$ & $\begin{array}{l}\text { Became familiar to } \\
\text { sprouted monggo seeds. }\end{array}$ & 15.3 & $\begin{array}{l}\text { Observing, Measuring } \\
\text { and Communicating }\end{array}$ \\
\hline Flowers & $\begin{array}{l}\text { Observing } \\
\text { photoperiodic plants }\end{array}$ & $\begin{array}{l}\text { Collect 4'oclock flower, } \\
\text { sunflower and calathea } \\
\text { plant family. }\end{array}$ & 16.0 & $\begin{array}{l}\text { Observing, } \\
\text { Inferring, } \\
\text { Predicting Communicating }\end{array}$ \\
\hline
\end{tabular}

The topic on animals got the highest mean score of 17.2 and 16.5. This explains that exposing pupils to technology-based activities increases their performance in the different science process skills. It also shows how it affects the pupils' further interest from the knowledge they acquired on the days after the experiment.

The first topic matches Communicating Skill, Classifying Skill, Inferring Skill, Predicting Skill, Measuring skill, and Observing Skills. The experiments are supported by Zulueta (2007) that learners integrate the subject matter by collecting data, observing, measuring, classifying and examining causal relationships. It is shown that Science experiments encourage learners to discover and develop new and fresh concepts or ideas, boost their mind to be critical and creative. Also, real-life applied activities and problem-solving activities establish a contextual setting for many lessons providing motivation and encouraging curiosity (Corpuz \& Salandanan, 2015).

According to Corpuz and Salandanan (2015), reflection is an authentic activity that make students realize on their choices and on their learning. Deeper learning happens when pupils are able to think about their experiences and process this.

Table 6, Table 7, and Table 8 illustrates the student's reflections to Science topics, namely; different trees, flowers, and animals found in their community. The researchers gathered the data every after discussions to know the impacts to them in reality. On the table, the pupils were asked, "If you are a plant, what plant you want to be and why?", twenty of them answered that they wanted to be a tree because it filters the air with their wide branches and leaves and can be made as furniture and firewood. Their answers display meaningful thinking on how important trees are to living things. On the contrary, the least answered plant was a vine plant, two (2) pupils answered that it filters the air with their long vines. Obviously, the answers were focused on the benefits given by the plants.

Table 6. Pupils' reflections on the topic plants

\begin{tabular}{lll}
\hline Kinds of plants & Reason & Frequency \\
\hline Tree & Can be made as furniture, firewood and filters the air with its wide & 20 \\
& branches and leaves. & \\
Shrub & Prevents soil erosion & 4 \\
Bush & Gives shed & 4 \\
Vine & Filters the air with its long vines and stems. & 2 \\
\hline
\end{tabular}


Table 7. Pupils' reflections on the topic flowers

\begin{tabular}{lll}
\hline Kinds of flowers & Reason & Frequency \\
\hline Sunflower & It can be eaten and has medicinal properties. & 15 \\
Sampaguita & Can be made as perfume. & 8 \\
Ilang-ilang & Can be made as perfume. & 3 \\
Rose & Has thorns for protection & 2 \\
Bougainvillea & Has thorns for protection & 2 \\
\hline
\end{tabular}

Another question asked was, "If you are a flower, what flower do you want to be and why?". Half of the class or fifteen (15) pupils answered that they wanted to be a sunflower because its seeds can be eaten and have numerous health benefits. Answers fall positively under Inferring Skill where they give reasonable explanations to their observations. The least answered kind of flowers was rose (2) and bougainvillea (2) with the same reasons that both have thorns to protect themselves from predators.

Table 8. Pupils' reflection on the topic animals

\begin{tabular}{lll}
\hline Domestic animals & Reason & Frequency \\
\hline Dog & Guards the house for 24/7 & 16 \\
Cat & Kills rats and snakes & 8 \\
Cow & Produce liters of milk and kilograms of meat. & 2 \\
Chicken & Produce dozens of eggs and kilograms of meat. & 2 \\
Goat & Produce liters of milk and kilograms of meat. & 2 \\
\hline
\end{tabular}

Lastly, the question, "If you are an animal, what animal do you want to be and why?" the researchers gathered five (5) kinds of answers. Almost half of the class or sixteen (16) pupils answered they wanted to be a dog because it guards and protects the house 24/7, it emphasizes the strong relationship between dog and human. Those reflections were deep because it affects them internally through emotions. However, six (6) more pupils equally wanted to be a cow (2), a chicken (2) and a goat (2) because they give kilograms of meat, dozens of eggs and liters of milk to humans. They were affected in reality.

Concrete experience provides information that serves as a basis for reflection. All reasons were identified under the following skills: observing skill, which they used their five senses namely; sight, smell, hearing, touch, and taste; measuring skills which they use the unstandardized and standardized unit in measuring; classifying as they identified the similar properties, communicating skills and predicting skills which they shared their ideas through written reports, diagrams and graphs and charts about the topics, and inferring skills which they made different assumptions from the topic.

The results of the pupils' reflection and reflecting skills has something to do with Kolb, Dewey and Piaget's Experiential Learning Theory, which educators purposefully engage with students in direct experience and focused reflection to increase knowledge, develop skills and clarify values (Association for Experiential Education, 2011). Furthermore, Bunga et al (2016) stated that writing allows learners to reflect on what they are learning and foster their active classroom involvement. In other words, all the BSPS are revealed in reflective writing.

To assess the pupil's achievement after the application of LARO lessons, a 30-item parallel post-test was administered. The outcome of the post-test was also recorded. A comparison of the pupils' scores in the pretest and post-test is presented in the table below to confirm the improvement of the pupils' BSPS.

Table 9 shows an increase of 11.87 from 16.06 mean score of the pre-test to 27.93 mean score of the post-test. After using the intervention, the pupils belonging to average level in the pre-test improved to outstanding in the post-test. It was found out that there is an improvement in the BSPS of the pupils in Science. Table 10 shows how all the learning competencies in both plants and animals increased, as shown in their post-test performance.

Table 9. Comparative result of pre-test and post-test

\begin{tabular}{|c|c|c|c|c|c|}
\hline \multirow{2}{*}{ Scores } & \multicolumn{2}{|r|}{ Pre-test } & \multicolumn{2}{|c|}{ Post-test } & \multirow[t]{2}{*}{ Rating } \\
\hline & $f$ & $\%$ & $f$ & $\%$ & \\
\hline $25-30$ & 5 & 16.67 & 30 & 100 & Outstanding \\
\hline $19-24$ & 17 & 56.67 & 0 & 0 & Above Average \\
\hline $13-18$ & 7 & 23.33 & 0 & 0 & Average \\
\hline $7-12$ & 1 & 3.33 & 0 & 0 & Below Average \\
\hline Total & 30 & 100 & 30 & 100 & \\
\hline Mean & & 16. $06(\mathrm{SD}=3.54)$ & & 1.23) & \\
\hline MPS & & 53.53 & & 90 & \\
\hline
\end{tabular}


Table 10. Comparison of the pupils' pre-test and post-test result by learning competency

\begin{tabular}{|c|c|c|c|c|c|}
\hline Learning competency & Item no. & $\begin{array}{l}\text { Pre-test } \\
\text { mean }\end{array}$ & Percentage (\%) & $\begin{array}{l}\text { Post-test } \\
\text { mean }\end{array}$ & Percentage (\%) \\
\hline $\begin{array}{l}\text { 1. Infer that body structures } \\
\text { help animal adapt and } \\
\text { survive in their particular } \\
\text { habitat. }\end{array}$ & $1-4$ & 24.75 & 83.00 & 30.00 & 100 \\
\hline $\begin{array}{l}\text { 2. Compare body movements } \\
\text { of animals in their habitat. }\end{array}$ & $5-8$ & 20.25 & 68.00 & 28.25 & 94.00 \\
\hline $\begin{array}{l}\text { 3. 3. Make a survey of animals } \\
\text { found in the community and } \\
\text { their specific habitat. }\end{array}$ & $9-12$ & 21.50 & 72.00 & 26.50 & 88.00 \\
\hline $\begin{array}{l}\text { 4. Choose which animals to } \\
\text { raise in a particular habitat. }\end{array}$ & $13-15$ & 24.67 & 82.22 & 26.67 & 89.00 \\
\hline $\begin{array}{l}\text { 5. Identify the specialized } \\
\text { structures of terrestrial and } \\
\text { aquatic plants. }\end{array}$ & $16-19$ & 19.25 & 64.00 & 26.50 & 88.00 \\
\hline $\begin{array}{l}\text { 6. Investigate the specialized } \\
\text { structures of plants given } \\
\text { varying environmental } \\
\text { conditions: light, water, } \\
\text { temperature, and soil type. }\end{array}$ & $20-23$ & 24.00 & 80.00 & 29.00 & 97.00 \\
\hline $\begin{array}{l}\text { 7. Survey plants found in the } \\
\text { community and their specific } \\
\text { habitats. }\end{array}$ & $24-26$ & 22.00 & 72.00 & 28.00 & 93.00 \\
\hline $\begin{array}{l}\text { 8. Choose which plants to grow } \\
\text { in a particular habitat. }\end{array}$ & $27-30$ & 18.00 & 60.00 & 28.67 & 97.00 \\
\hline
\end{tabular}

Learning competency number 1 under Animals got the perfect or outstanding performance in the post-test meaning that the pupils recognize that body structures help animal adapt and survive in their particular habitat. Learning competency number 4 under Plants got the highest percent gain of $37.00 \%$, from $60.00 \%$ to $97 \%$ this means that they can select which plants to grow in a particular habitat. The items under those competencies are observing, classifying and inferring Skills. The students evidently mastered those skills because those were mostly used on the topics. These learning competencies are crucial for providing students with the knowledge, skills and attitudes that they will need to effectively explore their personal journeys.

To recognize the improvement of the pupil's level of BSPS before and after the use of LARO lessons, a disparity of frequency distribution of scores each level of BSPS in the pre/post-test is conducted. It emphasized the effect of the technique in each process of BSPS. The introduction and exposure to LARO lessons' varied learning activities improved different Science process skills as what observed, increases the pupil's proficiency in work, formulated logical conclusion, and showed in their actions.

The level of BSPS of the pupils improved at all levels. Pupils improved much is the predicting skills from 23 to 30 mean in the pre-test and post-test respectively. They were able to foresee what may happen in their activities performed under the group works.

One of the goals of science teaching is to develop the skill with the use of the science processes and allow students to show what they have learned rather than catching them out or showing what they have not learned (Corpuz \& Salandanan, 2015). Monitoring pupil's progress is crucial to know how they improved in all areas of performance. A collaborative, authentic, and goal-oriented learning environment concerning the new industrial era's demand must also be strengthened (Rafanan et al., 2020; Rogayan, 2019). An observation report was done to measure and identify what level of performance the Grade IV class are. The observation report was based on a rubric carefully made to distinguish the class improvement in every skill.

Table 11 reveals the pupils' performance level in the six basic science process skills. Predicting skill has a level performance of five or outstanding which means that they can predict five or more possible outcomes of an event. This is true because they are exposed to different media. While the rest of the basic science process skills fall on level four performance described as above average as they used of their four senses to make observations, had classified four categories, had measure using four unstandardized and standardized units, had given four reasonable explanations on observations, and had recorded four information in any forms of communication. According to Santos and David (2017), basic processes are the fundamental activities required in scientific inquiry and they are the key skills that underlie all scientific investigations. 
Table 11. Summary of observation report on the basic science process skills' level of performance based on the post-test

\begin{tabular}{lll}
\hline Basic science process skills & Level of performance & Rating \\
\hline Observing & 4 & Above Average \\
Classifying & 4 & Above Average \\
Measuring & 4 & Above Average \\
Inferring & 4 & Above Average \\
Communicating & 4 & Above Average \\
Predicting & 5 & Outstanding \\
\hline
\end{tabular}

To further confirm the effectiveness of LARO lessons, a comparative test on the pre-test and post-test has been presented.

Table 12 shows that each basic science process skills increased by 11.86 mean gain. This implies that the use of LARO lessons really improved the pupil's performance in different science skills.

Table 12. $t$-test of the pre-test and post-test per basic science process skills of grade IV pupils

\begin{tabular}{lllll}
\hline Basic science process skills & t-Value & Tabular value & df & Decision \\
\hline Observing $(8$ items $)$ & 4.31 & 1.70 & 29 & Reject Ho \\
Measuring (4 items) & 5.13 & 1.70 & 29 & Reject Ho \\
Classifying $(7$ items) & 9 & 1.70 & 29 & Reject Ho \\
Communicating $(3$ items) & 2.54 & 1.70 & 29 & Reject Ho \\
Inferring $(5$ items) & 4.04 & 1.70 & 29 & Reject Ho \\
Predicting (3 items) & 5.52 & 1.70 & 29 & Reject Ho \\
Overall & 19.05 & 1.70 & 29 & Reject Ho \\
\hline
\end{tabular}

Based on the result of the paired t-test and the computed the $t$ value is 19.05 which is greater than the critical value of .05 level of significance with 29 degrees of freedom, therefore, the null hypothesis is rejected. Hence, there is a significant difference between the pre-test and post-test scores. The application of motivational games shows improvement in the Basic Science Process Skills of Grade IV pupils. This implies the effectiveness of the technique to the pupils. The implementation of the basic science process skills of Grade IV pupils is strongly validated by their significant participation and performance in their recitation, experiment and reflective writing.

Students' Recitation Logs with a mean of 26.06 increased from August to October. It only showed that the pupils were eagerly motivated, built self-confidence, and showed excitement in the class discussions. There was an improvement in Grade IV pupils' performance on their oral participation as recorded in their daily recitation logs. The mean of 81.67 on the set of experiments performed by the pupils using Laboratory Group Experiments corresponds to six (6) BSPS done during LARO intervention. The results explain that the more technology-based activities presented to pupils, the more chances they performed so the mastery of skills increases. Digital literacy facilitates better learning for the students (Baterna et al., 2020). Furthermore, reflective journals express the pupil's insights to reality, significant appreciation of the topics' importance, and deep awareness through emotions and positive traits.

\section{CONCLUSION}

The level of BSPS of grade IV pupils before the intervention is average. In terms of recitation, only a low percent of recitation log was recorded before the intervention. Exposure to varied activities with the introduction of educational games developed the pupils' BSPS. After using the LARO Lessons, with integrated games, the grade IV pupils showed improvement from average to outstanding level on the skills. This is also supported with higher percentage of recitation log of the pupils. After the application of LARO Lessons, the BSPS of the students are outstanding in predicting and above average in observing, classifying, measuring, inferring, and communicating. The use of LARO Lessons effectively improves the BSPS of the grade IV pupils as supported by the t-test for paired samples results.

The teacher may consider using LARO Lessons as a technique to further develop the pupils' Basic Science Process Skills. LARO Lesson is an effective strategy to improve pupils' skills in science; thus, science teachers may imply their strategy to make students more active, enthusiastic, and creative from the start until the end of instruction. Encourage to try out other strategies in teaching the same topic on the Basic Science Process Skills. Further and similar studies may be conducted to validate the results of this study. Thus, problems on students' discipline, materials needed, time allotment, design of the room and familiarity with tools and equipment during instruction using LARO lessons may also be addressed. 


\section{ACKNOWLEDGEMENT}

The authors are grateful to the pupils and their parents, their teacher, and the school principal for allowing them to conduct the action research project. The authors are also thankful to the College of Teacher Education of the President Ramon Magsaysay State University - San Marcelino Campus for the assistance in this research study. To the people who enhanced this paper, the authors appreciate you all.

\section{REFERENCES}

Acero, V. C., Javier, E. J, and Castro, H. C. (2015). Principles of teaching I. Rex Bookstore. https://www.rexe store.com/education-books-college-books/452-principles-of-teaching-i.html

Alberta Education. (2012). Competencies: Students competency. https://education.alberta.ca/competencies/ student-competencies/

Al-Mutawah, M. A., \& Fateel, M. J. (2018). Students' achievement in math and science: How grit and attitudes influence? International Education Studies, 11(2), 97-105. https://doi.org/10.5539/ies.v11n2 p97

Al-Tarawneh, M. H. (2016). The effectiveness of educational games on scientific concepts acquisition in first grade students in Science. Journal of Education and Practice, 7(3), 31-37. https://eric.ed.gov/?id= EJ1089788

Andersen, P., \& Vandehey, M. (2011). Career counseling and development in a global economy. Cengage Learning. https://www.cengage.com/c/career-counseling-and-development-in-a-global-economy-2e-an dersen/9780840034595PF

Ashby, J., Sadera, W. A., \& McNary S., W. (2011). Comparing student success between developmental math courses offered online, blended, and face-to-face. Journal of Interactive Online Learning, 10(3), 128140. http://www.ncolr.org/jiol/issues/pdf/10.3.2.pdf

Association for Experiential Education (AEL). (2011). Experiential learning. Northern Illinois University, Faculty Development and Instructional Design Center. https://www.researchgate.net/profile/Behrouz Ahmadi-Nedushan/post/How_is_theory_influencing_real_life/attachment/59d6332079197b8077990d 24/AS:373262614843392@1466004150654/download/experiential_learning.pdf

Bajak, A. (2014). Lectures aren't just boring, they're ineffective, too, study finds. Science, 12. https:// www.sciencemag.org/news/2014/05/lectures-arent-just-boring-theyre-ineffective-too-study-finds

Baterna, H. B., Mina, T. D. G., \& Rogayan, D. V. Jr. (2020). Digital literacy of STEM senior high school students: Basis for enhancement program. International Journal of Technology in Education, 3(2), 105-117. https://www.ijte.net/index.php/ijte/article/view/28

Bunga, J. B., Pilariza, C.A. \& Serrano, E. D. (2016). Principles of teaching 2. Adriana Publishing Co. https:// www.scribd.com/document/471243011/p-t-2-Jaaime-Bunga

Burgemeester, A. (2018). Jean Piaget's theory of play. Psychologized; physcology is everywhere. www.psy chologized.org

Cherry, K. (2019). How social learning theory works. www.nverywellmind.com

Corpuz, B. B. \& Salandanan, G. G. (2015). Principles of teaching 2. Lorimar Publishing, Inc. https:// books.google.co.id/books/about/Principles_of_Teaching_2_with_TLE.html?id=UPkKugEACAAJ\&redir _esc=y

Department of Education (2012). K-12 Curriculum guide. (2012). Department of Education. http://www. deped.gov.ph/wp-content/uploads/2019/01/Science-CG_with-tagged-sci-equipment_revised.pdf

Explorable. (2017). Convenience sampling. Explorable Think Outside the Box. https://explorable.com/ convenience-sampling

Fiksl, M., Flogie, A., \& Aberšek, B. (2017). Innovative teaching/learning methods to improve Science, technology and engineering classroom climate and interest. Journal of Baltic Science Education, 16(6), 1009. http://www.scientiasocialis.Itjjbse/?q=node/628

Graafland, M., Schraagen, J. M. C., \& Schijven, M. P. (2012). Systematic review of validity of serious games for medical education and surgical skills training. The British journal of surgery, 99(10), 1322-1330. https://doi.org/10.1002/bjs.8819

Jones, W. D., Daniel, S. \& Dimiduk K. (2010). Games in recitation: Increasing student engagement while teaching mass and energy balances in chemical engineering. Teaching Excellence Institute, Cornell University. http://www.nseresearch.org/2017/overviews/Daniel-bio.pdf 
Kamra, R. (2010). The importance of using games in the English classroom. http://englishtips.org

Kolb, D. A. (1984). Experiential learning: Experience as the source of learning and development. PrenticeHall. http://www.learningfromexperience.com/images/uploads/process-of-experiential-learning.pdf

Libradilla, H., Teves, K., \& Teves, A. (2015). Teaching effectively with use of game-based interactive mathematics. In International Conference on Trends in Economics, Humanities and Management (pp. 169-173). http://icehm.org/upload/4518ED0315090.pdf

Macanas, G. A., \& Rogayan, D. V. Jr. (2019). Enhancing elementary pupils' conceptual understanding on matter through Sci-vestigative Pedagogical Strategy (SPS). Participatory Educational Research, 6(2), 206-220. https://doi.org/10.17275/per.19.22.6.2

Martinson, B., \& Chu, S. (2009). Game-based learning in design history. In Handbook of research on effective electronic gaming in education (pp. 478-488). IGI Global. https://doi.org/10.4018/978-1. 59904-808-6.ch027

National Association for Research Science Teaching (NARST). (2015). Worldwide organization for improving science teaching and learning through research. National Association for Research Science Teaching. https://narst.org/sites/defaultffiles/2019-11/NARST_LSEP_2020.pdf

National Research Council. (1997). Science teaching reconsidered: A handbook. National Academies Press. https://www.nap.edu/catalog/5287/science-teaching-reconsidered-a-handbook

Philippine Daily Inquirer. (2017). Science education and a thinking society. in https://www.pressreader.com/

Plass, J. L., Homer, B. D., \& Kinzer, C. K. (2015). Foundations of game-based learning. Educational Psychologist, 50(4), 258-283. https://doi.org/10.1080/00461520.2015.1122533

Rafanan, R. J., \& De Guzman, C. Y., \& Rogayan, D.V. Jr. (2020). Pursuing STEM careers: Perspectives of senior high school students. Participatory Educational Research, 7(3), 38-58. https://doi.org/10.17275/ per.20.34.7.3

Rogayan, D. V. Jr. (2019). Retrospective evaluation of the science education program in a Philippine state university. International Journal of Innovation, Creativity and Change, 8(7), 352-369. https://eric. ed.gov/?id=ED603046

Rogayan, D.V. Jr. \& Macanas, G. (2020). AGHAMIC Action Approach (A3): Its effects on the pupils' conceptual understanding on matter. Journal for the Education of Gifted Young Scientists, 8(1), 223240. https://doi.org/10.17478/jegys.635161

Santos, M. D., \& David, A. P. (2017). Self-and teacher-assessment of science process skills. The Normal Lights, 11(1), 91-108. https://po.pnuresearchportal.org/ejournal/index.php/normallights/article/view/377

SEAMEO INNOTECH. (2016). Nurturing critical and creative thinkers through inquiry-based teaching and learning in early childhood care and education. SEAMEO INNOTECH. https://www.seameoinnotech.org/wp-content/uploads/2016/10/IBTL.pdf

SEI-DOST \& UP NISMED. (2011). Science framework for Philippine basic education. Science Education Institute, Department of Science and Technology (SEI-DOST) \& UP NISMED. http://www.sei.dost. gov.ph/images/downloads/publ/sei_scibasic.pdf

Singh, R. P. \& Padilla, C.P. (2009). Innovative teaching and evaluation. National Bookstore. https://books.google.co.id/books/about/Innovative_Teaching_and_Evaluation.html?id=VD-IAQAACAA J\&redir_esc=y

Tizon, M. N. (2009). Vocabulary ability of BSN 1 students of La Salle University. Lasallian Research Forum, 14(4), 59-78. https://www.scribd.com/document/264818838/Nocabulary-Ability-of-BSN-1-Students-ofLa-Salle-University

Tolentino, A., Roleda, L. \& Prudente, M. (2018, August 2-3). Gamified instruction and its effect to student motivation and achievement in Science. In Proceedings of 126th ISERD International Conference, Singapore. https://www.academia.edu/37139446/Gamified_Instruction_and_Its_Effect_to_Student_M otivation_and_Achievement_in_Science

University of Washington. (n.d.). Understanding item analyses. https://www.washington.edu/assessment/scan ning-scoring_trashed/scoring/reports/item-analysis/

Viray, J. S. (2016). Engaging students through board games: Measuring its effectiveness on academic performance. International Journal of Scientific and Research Publications, 6(10), 5-7. http://www. ijsrp.org/research-paper-1016/ijsrp-p5803.pdf 
Yen, J. C., Tsai, C. H., \& Wu, M. (2013). Augmented reality in the higher education: Students' science concept learning and academic achievement in astronomy. Procedia-Social and Behavioral Sciences, 103, 165-173. https://doi.org/10.1016/j.sbspro.2013.10.322

Zulueta, F. (2007). Principles and methods of teaching. National Bookstore. https://cfmslibrary.librarika.com/ search/detail/626912 